\title{
The Role of Customary Law Community of Moronene Hukaea Laea in Managing Ulayat Forests in the Rawa Aopa Watumohai Conservation Area
}

\author{
Jabalnur, Heryanti, Sahrina Safiuddin, Nur Intan \\ Faculty of Law, Haluoleo University, South East Sulawesi, Indonesia
}

\begin{abstract}
Customary law community is identical with Ulayat (customary) rights to their customary tenure areas. The recognition of the existence of ulayat rights is implemented in a number of laws and regulations. The customary law community has a very big role in maintaining the preservation of customary territories, especially in customary forests that are heavily guarded because of their safety. In carrying out their lives in their customary territories, they are very strict with the principles of local wisdom that are regulated according to the customary law. One of them is opening up shifting plantation land and has been regulated in customary regulations. Land management and utilization of natural resources around it is done traditionally based on the knowledge possessed and become a habit that is adopted in the customary law. Customary law community.of Moronene Hukaea Laea is indigenous people who live based on ancestral ancestors over a customary area, which has sovereignty over land and natural resources, social and cultural life governed by customary law and traditional institutions that manage the continuity the life of its people so far.

Keywords: Management of Ulayat Forests; Rawa Aopa Watumohai Conservation Area; Moronene Hukaea Laea; DOI: $10.7176 / \mathrm{JLPG} / 90-06$
\end{abstract}

Publication date:October $31^{\text {st }} 2019$

\section{Introduction}

After Indonesia's independence, the existence of customary law communities and their biodiversity gained a constitutional foundation through article 18 of the 1945 Indonesian Constitution which stipulates that the division of Indonesian regions over large and small regions, with the form of governmental structure determined by law, by looking and remembering the basis of deliberations in the system of state government, and the rights of origin in special regions. The recognition and constitutional protection of the customary law community was not lost after the 1945 Indonesian Constitution was amended where the recognition and protection of the customary law community was at least stated in Article 18 B paragraph (2) and Article 28 I paragraph (3) of the 1945 Indonesian Constitution.

Customary law community is identical with ulayat rights to their customary tenure areas. The recognition of the existence of the ulayat rights is implemented in the Law No. 41 of 1999 concerning Forestry to become the Law No. 19 of 2014 concerning the establishment of the Government Regulations in lieu of the Law No. 1 of 2014 concerning amendment of the Law No. 41 of 1999 on forestry. Article 1 number 6 the Law No. 19 of 2014 states that indigenous forests are state forests located in the area of customary law. Article 67 paragraph ( 2 ) further states that the confirmation of the existence of customary community is through regional regulations.

In the 1992 Rio De Jeneiro Declaration ( The Rio De Jeneiro Declaration on Environment and Development ) produced 27 principles. One of the principles governing indigenous and local people is regulated in principle 22 which states "indigenous and local people have an important role in environmental management and development because of their traditional understanding and knowledge". States must recognize and fully encourage their identity, culture, desires, and strengthen their effective participation in achieving sustainable development. The consequences of the policy or legal politics of UN member states should be in line with the contents of the various conventions and declarations.

In Indonesia, the push for the Government to immediately issue implementing policies towards the recognition and protection of indigenous peoples continues to roll. Since Congress of the Archipelago of Indigenous Peoples (KMAN) II held in Lombok in 2004 until KMAN IV in Tobelo North Halmahera in 2012, nearly 3,000 customary communities incorporated to the Archipelago of Indigenous Peoples Alliance (AMAN) continuously urging the government to, among other things: speed up the process of discussion and ratification of the bill of Indigenous Peoples; repeal various laws that become a source of conflict and human rights violations in customary communities and replace them with legal products that provide formal recognition of the customary territories following its management by the customary communities. The government basically has responded to the insistence of the customary community. In 2006, President Susilo Bambang Yudhoyono, during his speech in the celebration of the International Day of Indigenous People in Taman Mini Indonesia Indah has signalled the importance of the country to make efforts in the protection of the customary community. 
One of the customary law community in Indonesia is the Moronene Hukaea Laea. The customary law community of the Moronene Hukaea Laea is indigenous people / natives who live based on the ancestor from generation to generation over a customary territory, who has sovereignty over land and natural resources. Their social and cultural life are governed by the customary law and customary institution which manages the sustainability of people's lives over the years.

In the history of South East Sulawesi, the customary law community of the Moronene Hukaea Laea is the customary law community who first inhabited the mainland of Southeast Sulawesi, together with Tolakinese and Mekongga. The customary law community of the Moronene spread across 6 sub-districts. One of the customary law communities of the Moronene is located in Rumbia sub-district. It is divided into 11 Tobu (customary territory) and its customary institution leadership is named as Mokole. They have managed their ancestral territories in Hukaea Laea, Lampopala and surrounding areas since the 1920s. The village land used for gardens, buffalo and horse grazing land, teak gardens, shared ponds at river mouths, graves and others. In 1952, 1953 and in 1960, they were forced to flee their ancestral lands because of security problems by the gangs and now they live scattered in the surrounding villages after several times collected and moved. Accessibility of the customary community on gardens, farms, and grazing fields have begun to be restricted to designated as a hunting park in 1972. In 1980, the region became the candidate of the National Park and in 1990 was appointed as a National Park Rawa Aopa Watumohai. The process of land acquisition in the forest area takes place without going through a process of deliberation. Their struggle for recognition of the customary rights conducted since 1987 by writing repeatedly to the Vice President of Indonesia and Project Manager TN. An oral agreement with the Regional Government Joint Team chaired by Head of Social Politic Office on 16 December 1997 was agreed that the community would remain in their village and utilize the yields of gardens and forests as usual while waiting for talks with the leadership. ${ }^{1}$

To reduce the conflict occurred by the Regional Government through the Regional Regulation (Perda) of Bombana Regency No. 4 of 2015 concerning Recognition, Protection and Empowerment of Moronene Indigenous Peoples in Hukaea Laea. The Perda is an implementation of the mandate of Article 67 of the Law No. 41 of 1999 concerning Forestry on the inaugural indigenous legal community presence. However, the existence of the Perda was still not dampen conflict in particular with key stakeholders. The perda does not also recognize customary rights over the area of the old village (Tobu) of the customary law community of the Moronene Hukaea Laea.

The implementation of the Perda No. 4 of 2015 on Recognition, Protection and Enforcement of the customary law community of the Moronene Hukaea Laea cannot yet be implemented because of the existence of the Law No. 5 of 1990 concerning Conservation of Biological Resources and their Ecosystems. In several articles of the Law No. 5 of 1990 mention that the National Park is a nature conservation area that has an original ecosystem, managed with a zoning system that is utilized for the purposes of research, science, education, supporting cultivation, tourism and recreation. Everyone, therefore, is prohibited from carrying out activities that can cause changes to the integrity of the nature reserve area. Everyone also is prohibited from taking, cutting, possessing, damaging, destroying, maintaining, transporting and trading in protected plants or parts thereof in a state of life or death. The violation of those articles will be sanction of imprisonment for 10 years and a fine of Rp. 200,000,000.00.

On the other hand, the customary law community has a very big role in maintaining the preservation of customary or ulayat areas, especially in customary forests that are heavily guarded because of their safety. In taking their life in the customary region, the customary law community uphold the principles of local wisdom that governed by the customary law. One of the principles can be seen in the context of opening up of shifting plantation land as regulated in the customary regulations. Land management and the use of natural resources around it is done traditionally based on the knowledge that is owned and is a habit that is shared by the customary law community of Moronene Hukaea Laea. The pattern of management carried out by indigenous people (natives) is proven to be able to preserve the natural resources of their forests compared to forests managed by national legal patterns. The focus of this article then is the role of the customary law community of Moronene Hukaea Laea in the management of customary forests in the conservation area of the Aopa Watumohai Rawa National Park?

\section{Literature Review}

\subsection{The Customary Law Community}

The term of the customary law community is a legal term that is contained in the various laws and regulations, such as the Law No. 5 of 1960 on Basic Regulation of Agrarian (BAL), the Law No. 41 of 1999 on Forestry, the Law No. 39 of 2014 on Plantation, and other laws and regulations as an equivalent of rechtgemeenschapt, or a

\footnotetext{
${ }^{1}$ Martua Sirait, et al, 1999, How the Rights of Indigenous Peoples in Managing Natural Resources is Regulated, Southeast Asia Policy Research Working Paper, p. 16.
} 
little literature calls it adatrechtgemenschap. The term of the customary law community is born and is used by customary law experts who are more functioned for academic theoretical purposes. While the term indigenous peoples (the customary community) is a term commonly expressed in everyday language by non-law groups which refers to a number of international agreements. ${ }^{1}$

The customary law communities are organized groups of people who behave as a unit, settle in certain regions, have authorities, have their respective customary laws, and have their own wealth in the form of tangible or intangible objects and control of natural resources within its reach. ${ }^{2}$ They have a complex cultural system in their social order and have a strong relationship with their land and natural resources. They are also defined as a group of people who are bound by their customary legal arrangements as a common citizen of an alliance because of the similarity of their dwelling or descent. ${ }^{3}$ According to Hazairin, the customary law communities are community units that have the provisions to be able to stand on their own who have legal unity, unity of authority and environmental unity based on the common right to land and water for all its members. ${ }^{4}$ The leaders of the customary community who are members of AMAN formulate customary law communities as a group of people who are bound by their customary legal arrangements as joint citizens of a legal alliance because of the similarity of their dwellings or on the basis of descent. ${ }^{5}$

\subsection{The Ulayat (Customary) Rights}

Article 3 of the BAL states that the term Ulayat rights is not a single name. In other regions in Indonesia, there are those who call it Pertuanan. ${ }^{6}$ Van vollenhoven stipulates the term beschikking srecht. ${ }^{7}$ Furthermore, Suriyaman Mustari Pide states that the term for the Ulayat rights as the collective rights of the customary law community over land. ${ }^{8}$ The Ulayat rights are the highest tenure rights over land in customary law which includes all land included in the territory of a particular customary community which belongs to the common land of its citizens. ${ }^{9}$ According to Narullah Datuk Perpatih Nan Tuo, ${ }^{10}$ the Ulayat rights are the power or authority that indigenous peoples have over certain areas or spaces to enjoy the benefits of natural resources for survival arising from outward and inner relations from generation to generation from the ancestors of the current generation which are passed on to future generations against land located in the area of its territory.

The Ulayat land itself is a parcel of land on which there are the Ulayat rights from a particular community. ${ }^{11}$ Certain community groups can be customary law communities formed based on territoriality and can also be based on genealogic. There are 3 types of the Ulayat land based on their control, namely: Tanah Ulayat Nagari, Tanah Ulayat Suku, and Tanah ulayat Kaum. The customary land for the customary law community is a place of life and livelihood and maintain the existence of the group to continue to exist among other groups that are watching. The Ulayat ustomary land is a binding element for people who live in an area and is a genuine determining factor whether someone comes from an area.

\subsection{Conservation}

Conservation implies an effort to use natural and biological resources, but also efforts to prevent the depletion of natural resources so that natural resources remain available. Without the prevention of depletion of resources, then slowly, but surely resource ala m biodiversity will run out one day. ${ }^{12}$ According to the Law No. 5 of 1990 concerning Conservation of Living Natural Resources and their Ecosystems, Conservation of living natural resources is the management of living natural resources, the use of which is carried out wisely to ensure the continuity of its supplies while maintaining and increasing the quality of diversity and value.

\section{ResearchMethods}

\subsection{Research Type}

This research is a normative research or doctrinal research equipped with empirical data, which review and analyse the legal protection Moronene indigenous peoples in the conservation area. Types of normative research

\footnotetext{
${ }^{1}$ Taqwaddin , 2010, Mastery of the Management of Customary Forests by the Law Society (Mukim) in the Province of Aceh, Dissertation of Doctor of Law, North Sumatra University, p. 36.

${ }^{2}$ Ibid

${ }^{3}$ Limei Pasaribu, 2011, The Existence of Customary Rights in the Batak Toba Customary Law Community in Nassau Subdistrict, Toba Samosir District, Thesis, Legal Studies, Notary Masters Study Program, USU.

${ }^{4}$ Rikardo Simarmata, 2006, Legal Recognition of Indigenous Peoples in Indonesia, UNDP Regional Center in Bangkok, Jakarta, p. 23.

${ }^{5}$ Husen Alting, 2010, Legal Dynamics in the Recognition and Protection of the Rights of Indigenous Peoples of the Land, LaksBang PRESSindo, Yogyakarta, p. 31.

${ }^{6}$ Moh. Koesnoe, 2002, "Capita Selecta of Customary Law: A New Thought”, Varia Peradilan, Jakarta, p. 118 .

${ }^{7}$ Ibid.

${ }^{8}$ Suriyaman Mustari Pide, 2007, Collective Rights: Dilemma and its reality post the BAL, Pelita Pustaka, Jakarta, p. 7 .

${ }^{9}$ Ibid.

${ }^{10}$ Ibid., p.29.

${ }^{11}$ Ibid.

${ }^{12}$ See Takdir Rahmadi, 2012, Environmental Law in Indonesia, Raja Grafindo Persada, Jakarta.
} 
include research on the principles of law, legal systematics, comparative law, inventory of positive law, philosophical basis (dogma or doctrine) positive law. ${ }^{1}$

\subsection{Research sites}

The research was carried out on the indigenous people of Moronene Hukaea Laea as a community of indigenous peoples who carry out customary forest management in their customary territories as part of the Rawa Aopa Watumohai National Park.

\subsection{Types and Sources of Legal Materials}

Types of legal materials used in this study are primary and secondary data. The primary data is obtained in the field at the research location and the secondary data are derived from the literature relating to the research object. Sources of legal materials used are primary and secondary legal materials. The primary legal materials obtained by examining several international instruments in relation to protected area management involving indigenous peoples, as well as the Amendment 1945, the Law No. 41 of 1999 on Forestry, and other legislation that became the basis for the designation of conservation area as if the Law No. 5 of 1990 on the Conservation of Biological Resources and their ecosystems. The secondary legal material provides instructions and explanations to support primary legal material and they can be seen from books, scientific journals, papers, research results, opinions of legal experts in connection with the issues to be discussed.

\subsection{Data collection technique}

Data are collected through observations and interviews with the customary law community and the Rawa Aopa Watumohai National Park.

\subsection{Data analysis}

All sources of legal materials collected in this study, both in the primary, secondary, and non-legal sources will be processed by the analytical approach according to the nature and character of normative legal research. The primary source of legal material is carried out by carrying out an inventory of positive laws, both in the form of laws and regulations and all other regulations that are related to this research. In analyzing all sources of legal materials, especially those relating to legal ideas, the analysis uses normative / prescription analysis, which is an analysis derived from the decisions of the customary institutions that will be related to legal issues in this research. On the other hand, the analysis was also carried out with a descriptive approach, namely displaying the content or meaning of the customary institution decisions used in the study.

\section{Discussion}

Forests are high diversity of natural resources and since ancient times the forests have been used to meet human

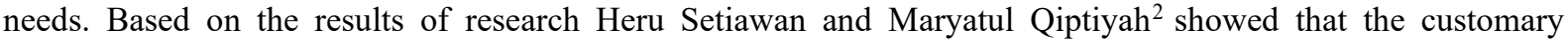
community of Moronene use the plants for food sources, medicines and ceremonial customary purposes as many as 124 species consisting of 68 species for food resources, 65 kinds of medicines, and 10 kinds for ceremonial purposes. There are several types of plants with more than one utility, the plant's of Lanu (Corypha Utan) used for food resources and the customary ceremony. The highest utilization of plants is leaves with 52 types of plants, fruits with 40 types of plants, then tubers, and bark with the same number of species, namely plants, stem parts with 8 types of plants, other parts (sap) as many as 6 types of plants and root section with 4 types plants.

Plants for sources of food, medicine and ceremonial purposes of the customary community of Moronene largely derived from the community land area of Moronene contained within the National Park Rawa Aopa Watumohai (TNRAW) around 44206.16 ha. As the region is the source of life and the source of life supernatural the customary community of Moronene, amid limited access to communal of the customary community of Moronene. Even though the access is only in the traditional zone role of the customary institution to implement its own law in order to guarantee balancing of nature and preserving Rawa Aopa Watumohai National Park area as a strategic area in Indonesia. To understand the role of the customary community of Moronene Hukae Laea in the management of customary forests in the Aopa Watumohai Rawa National Park area, the meaning of the role will first be stated.

The meaning of role is a complex of human expectations about the way individuals must behave and act in certain situations based on their social status and function. ${ }^{3}$ Furthermore, Soerjono Soekanto ${ }^{4}$ defines the role as the exercise of the rights and obligations of a person or institution according to his position (status). In the

\footnotetext{
${ }^{1}$ Soerjono Soekanto, 1986, Introduction to Legal Research, UI Press, Jakarta, p. 44.

${ }^{2}$ See Heru Setiawan and Maryatul Qiptiyah, 2014, "Study Ethnobotany Indigenous peoples Tribes Moronene in Rawa Aopa Watumohai National Park”, Jurnal Penelitian Kehutanan Wallacea, Vol. 3 No. 2, Juni 2014.

${ }^{3}$ See Abu Ahmadi, 1982, Social Psychology, PT Bina Ilmu, Surabaya.

${ }^{4}$ Soerjono Soekanto, 2002, Theory of Role, Bumi Aksara, Jakarta, p. 243.
} 
context of Soerjono Soekanto's opinion, the intended role is the normative role in relation to the duties and obligations in law enforcement in total enforcement. ${ }^{1}$

The role of the customary law community of Moronene Hukae Laea is the role in the implementation of rights and obligations under the customary law in forest management in the National Park of Rawa Aopa Watumohai. The role of the customary law community of Moronene Hukae Laea in the management (conservation) of natural resources (forests), can be seen in two forms, namely: (1) aspects of regulation; and (2) aspects of institutional customary policies. First, from the aspect dimensions of the implementation the customary law management and use (conservation) of forest, it can be found in the system of agricultural fields, which all the processes and stages of implementation following the procedures referred to the customary law as stated by the ancestors for generations until now.

The customary law has become a guideline for the culture of agriculture fields. It means that the process and its phases must follow the hereditary customary law resulted from forefathers of Moronene. Therefore, in managing and utilizing (conservation), there are several roles carried out by the Customary Law Community, as followings:

1. The Role of Customary Institutions of the Customary Law Community of Moronene Hukae-Laea in the regulation of grouping forest areas.

The grouping of forest areas can be processed by the customary law community through applying the customary law called " $\boldsymbol{m} \boldsymbol{e}^{\prime} \boldsymbol{u} \boldsymbol{m a}$ " (traditional farming law) by the customary institutions of the customary law community of Moronene Hukae Laea. The "me'uma" customary law regulates the grouping of land / forests in the customary area with the intention that the community can know which forest areas can be managed / utilized according to their functions, and which ones must be secured and should not be encroached upon, for security reasons and their own needs. ${ }^{2}$

According to the "me'uma" customary law, land or forest areas are grouped in 4 (four) forest zones / groups, namely: (1) Inalahipue area (core forest / protected forest as a buffer for ecosystem life in the downstream). (2) Inalahi Popalia area (sacred forest), (3) Inombo area (production forest, for agricultural and plantation areas and the necessities of life for the community), and (4) Lueno area, which is "savannah desert". The four areas are also believed by the Customary Law Community of Moronene Hukae-Laea. Each of which has a "waiting", called the Toriano Inalahi (forest area), the retainer is called (Nteiwonua). Toriano e'e, (Tomie'e), and Toriano Lueno (Tomilere). In customary faith, it is characterized by their belief traditions which require to perform the ritual Mo'ooli (redemption customary) or permits in place whenever any important activities. For example, opening new villages, opening new agricultural areas, hunting, and so on.

According to the information and stories of the Customary Law Community of Moronene Hukae-Laea, ${ }^{3}$ in the area around the "Inalahi pue" and "Peuma" or other sacred forests, sometimes there are missing persons caused by the beliefs of the Customary Law Community of Moronene Hukae-Laea. The missing person is hidden by spirits or lost in the wrong direction, or someone who comes to forest above is sometimes sickly called (Mongkonai). The term "Mongkonai" literally means "grasping / grabbing spirits". The characteristics of people "Mongkonai" is if people suddenly get sick after coming from the forest, such as dizziness (Mokolili), fever (Moreo) until the vomiting is yellow. If a person is sick due to "Mongkonai", he/she usually cannot be cured by medical treatment because he/she must be treated traditionally by Pembue'a or Wolia with certain spells, before treatment to medical methods.

The forest is also a place in the ceremonies and rituals called "Moli Wanua" held annually by the Customary Law Community of Moronene Hukae-Laea. "Moli Wanua" is done to ask permission to enter the area, coupled with the "Montewali Wonua" ceremony (village washing). Inalahipue is a primary forest which has an area of 4,623.44 hectares. It is believed mythologically to be a place where spirits are called Ntiwonua. ${ }^{4}$

Inalahipue Forest has functions as (1) buffer forest to support all ecosystem life in downstream areas; (2) protection forest of "groundwater" sources (Mata Bundu), small rivers that become headwaters of large rivers, such as the Laea River, Mandu-Mandula River and others, which are located in the upstream area of Hukaea Laea; (3) produced forests to create food sources such as tubers, vegetables, and plants / medicines; (4) protection of clan wildlife. With this function, the Inalahipue forest is established by the Customary Institution of Moronene Totongano Wonua, Huka'e Laea as a "protected forest" or "core forest" must be protected from damage caused by human hands. It is because this forest must not be encroached upon and / or endeavoured for individual interests. Forest products from Inalahipue can only be used for "customary purposes" approved the Customary Institution of Moronene Totongano Wonua.

\footnotetext{
${ }^{1}$ Soerjono Soekanto 1987, Sociology of Law in Society, Rajawali, Jakarta, p. 220.

${ }^{2}$ Interview with Agricultural Shaman, Meo (66 Years), on 17 February 2019.

${ }^{3}$ Interview with Hukaea Laea native, Bakati (81 Years), on 17 March 2019.

${ }^{4}$ Jabalnur and Nur Intan, 2017, “ Management Model With the Customary Law Cummunity Participation in the National Park of Rawa Aopa, Bombana Regency”, Jurnal Ius Constituendum, Volume 2 Nomor 2 Tahun 2017, p. 149.
} 


\section{Regulation of Utilization of the Ulayat Land Area of Hukaea Laea}

For the Customary Law Community of Moronene Hukae-Laea, natural resources consisting of forest areas, rivers and other natural environments are part of their daily needs. Thus, the values of Moronene's customary in Hukaea Laea states that the people is not prohibited to utilise the forests anywhere, but do not be greedy. To maintain and ensure the sustainability of the forest after taking, it must replant. If humans do not consume forest products, save the seeds or "replant" on vacant land. People must love plants and the environment by planting back. Like the philosophy of Dayak life that before taking something from nature, humans must give to nature first. This means that in principle people can cut down and burn trees in the production forest area to be used as fields, but after that they must be planted again. Forest damage generally occurs because people forget to plant. ${ }^{1}$

The value of local wisdom is the view of the local community which states that "trees in the forest are essentially living things that will eventually die. Therefore, before it is dead that it must be utilized". They argue that the value of local wisdom is to place the function of the forest as a gift from God that must be utilized for human needs, but after that it must be replaced by replanting. The big trees cut down basically have benefits both for development and human needs and for the sustainability of forests in general. Small trees previously could not develop because they are obstructed by large trees form getting enough sunlight.

Utilization of the Ulayat forest area in Hukaea Laea in essence cannot be separated from the concept of conservation of natural resources as sated in the Law Number 5 of 1990. Conservation of natural resources, is "a form of management of biological natural resources whose its usage is done wisely to guarantee balance of its inventory, while maintaining and improving the quality of diversity and its value. It is similar to the concept of forest resources as stated in the Law Number 41 of 1999. Article 1 paragraph (2) states that forests are "a unified ecosystem in the form of a stretch of land containing biological natural resources dominated by trees in their natural environment with one another".

Utilization of forest area basically covers the use of "natural resources" and "biological resources". As natural resources, the forests area are utilized including the unity of ecosystems in a stretch of land containing biological natural resources dominated by trees in the natural environment alliance which cannot be separated. Then, as a biological resource, the utilization of forests area are all the natural potential that lives in a certain area, such as plants and animals (flora and fauna) that can provide benefits to human life and the natural surroundings, including forests as one element of biological natural resources.

Implementation of the customary law is derived from the values of local wisdom to the utilization of natural resources / forests. The "local knowledge" can be applied in two (2) forms, namely (1) local knowledge as a form of " custom, manners, and specific rules within the system of agricultural fields; (2) local wisdom in the form of "policy / regulatory of customary agencies, who set the order in the management / utilization of natural resources, especially in the four (4) out of 8 (eight) divisions of areas of forest management by Hukaea Laea natives. The utilization of the Inalahipue Zone, the utilization of the Inalahi Popalia Zone, the utilization of the Inombo Forest, and the utilization of the Lueno Zone.

Adherence to the regulation of forests area of indigenous peoples is based on their belief to their Gods who control the universe. In agricultural fields of the Customary Law Community of Moronene Hukae-Laea, it should apply local knowledge in accordance with the pattern of agricultural traditions fields ranging from early stages of cultivation until the end of harvest. In other words, all forms of human activities must be careful, not to violate the etiquette of the Gods. Based on this belief, it encourages the mentality of the community to always obey the restrictions in managing natural resources.

With this mental attitude, it has formed a collective awareness for the indigenous people of Moronene Hukaea Laea to treat and manage natural resources properly. This awareness factually can be seen in the form of the behaviour and actions of the Customary Law Community of Moronene Hukae-Laea who are always friendly to nature. They cut down trees not arbitrarily, except for important needs. These attitudes and behaviours will in turn become a pattern of action in the context of efforts to conserve natural resources through daily activities, both economic activities and other activities related to forests. Thus, forests are exploited efficiently and effectively, according to what they needed. It means that forests must be managed efficiently and effectively, so that forest destruction can be avoided.

3. Implementation of Customary Sanctions

The Customary Institution of the Customary Law Community of Moronene Hukae-Laea plays an important role in establishing customary law for the management of forest areas included in their Ulayat originating from local wisdom values. It also plays a role in enforcing customary law rules in order to achieve a life balance between humans and other humans or between humans and the universe. The life balance is included in the management of conservation areas in their customary territories.

The existence of unwritten customary law is called Adatino Totonggano Wonua. This customary rule functions when there are problems or disputes within the customary community's territory, either done by

\footnotetext{
${ }^{1}$ Agung Nugraha, 2005, Rindu Ladang, Perspective of Forest Village Community Change, Wana Aksara, Banten Indonesia, p. 173.
} 
Hukaea Laea indigenous people or outside Hukaea Laea communities. This customary law regulates forest management consisting of Innalahi pue, Innalahi popalia, Innalahi peuma, Olobu ea or Olobu ngkinonea, Olubu ute, Olobu popalia, meadow, utilization and collection of forest products (wood, rattan, resin), plantations, cultivation and paddy fields, rivers, traditional salt ponds Peo, Bolo (traditional fish ponds), animals (deers), and birds. When carrying out the restrictions as follows: enter, process, use, burn, take, kill, damage, cut, use for individual salt ponds, catch fish, hunt deer or Anoa, there will be then sanctions to carry out social work at the Customary Law Community of Moronene Hukae-Laea in a custom hall, mosque, school house, and other public facilities and plant trees when it comes to felling trees at Innalahi pue and Innalahi popalia. The most severe sanctions are expelled from the Customary Law Community of Moronene Hukae-Laea. The key word for this model is the unwritten customary law called Adati Tongano Wonua specifically sanctions for planting trees

In the period 2018-2019, there were violations of customary law carried out by parties of the customary law community as many as 5 people. They had been sanctioned by customary institutions. There were also violators of customary law from non-customary law communities and they had been given sanctions in the form of confiscation of deer meat obtained through meshing. Withdrawing the violation, the offender was handed over to the Natural Resources Conservation Center in the Aopa Watumohai Rawa National Park area for further legal proceedings. This means that there is collaboration between customary law and state law in handling traditional law violators from parties outside the customary law community as well as to maintain an atmosphere of harmony between customary law communities in the Bombana regency.

Forest functions for the Customary Law Community of Moronene Hukae-Laea is very significant, fundamental, and has a dependency. The efforts made for the people of the Kampo community of Hukaea Laea hereditarily passed on to his generation. The Kampo is to cling on efforts to protect and manage forests on the principle of fairness sustainable. It is supported and strengthened within the agency / customary institution.

\section{Conclusion}

The role of the Customary Law Community of Moronene Hukae-Laea in forest management of Ulayat forests located in the Rawa Aopa Watumohai National Park consists of the role of the Customary Institution of the Customary Law Community of Moronene Hukae-Laea in terms of governing of forest area grouping, utilization of forest areas of the Ulayat land, and the role of the Customary Law Community of Moronene Hukae-Laea in applying the customary sanction for customary violators in relation to the management of customary forests within the territory of conservation which is essentially the implementation of the management with the involvement of indigenous peoples of Hukaea Laea in the National Park Rawa Aopa Watumohai.

\section{Bibliography}

Abu Ahmadi, 1982, Social Psychology, PT Bina Ilmu, Surabaya.

Agung Nugraha, 2005, Rindu Ladang, Perspective of Forest Village Community Change, Wana Aksara, Banten Indonesia.

Heru Setiawan and Maryatul Qiptiyah, 2014, "Study Ethnobotany Indigenous peoples Tribes Moronene in Rawa Aopa Watumohai National Park”, Jurnal Penelitian Kehutanan Wallacea, Vol. 3 No. 2, Juni 2014.

Husen Alting, 2010, Legal Dynamics in the Recognition and Protection of the Rights of Indigenous Peoples of the Land, LaksBang PRESSindo, Yogyakarta.

Jabalnur and Nur Intan, 2017, “ Management Model With the Customary Law Cummunity Participation in the National Park of Rawa Aopa, Bombana Regency”, Jurnal Ius Constituendum, Volume 2 Nomor 2 Tahun $2017: 149$.

Limei Pasaribu, 2011, The Existence of Customary Rights in the Batak Toba Customary Law Community in Nassau Subdistrict, Toba Samosir District, Thesis, Legal Studies, Notary Masters Study Program, USU.

Martua Sirait, et al, 1999, How the Rights of Indigenous Peoples in Managing Natural Resources is Regulated, Southeast Asia Policy Research Working Paper.

Moh. Koesnoe, 2002, "Capita Selecta of Customary Law: A New Thought", Varia Peradilan, Jakarta. .

Rikardo Simarmata, 2006, Legal Recognition of Indigenous Peoples in Indonesia, UNDP Regional Center in Bangkok, Jakarta.

Soerjono Soekanto, 2002, Theory of Role, Bumi Aksara, Jakarta.

1987, Sociology of Law in Society, Rajawali, Jakarta.

--------, 1986, Introduction to Legal Research, UI Press, Jakarta.

Suriyaman Mustari Pide, 2007, Collective Rights: Dilemma and its reality post the BAL, Pelita Pustaka, Jakarta. Takdir Rahmadi, 2012, Environmental Law in Indonesia, Raja Grafindo Persada, Jakarta.

Taqwaddin, 2010, Mastery of the Management of Customary Forests by the Law Society (Mukim) in the Province of Aceh, Dissertation of Doctor of Law, North Sumatra University. 